\title{
PEMBELAJARAN KEAKSARAAN FUNGSIONAL DAN KECAKAPAN HIDUP WARGA BELAJAR
}

\begin{abstract}
Mokhamat Muhsin*
Abstract

Having been developed for years, a program on literacy is one of nonformal education one of objectives is to improve the quality of life of the society. The research raises questions on (1) whether the existing literacy program provides its participants with life skill improvement reality, (2) whether practicing the skills would improve the quality of their life. Being akcnowledge of the program, the head of subdistrict responds positively to its progress.
\end{abstract}

Key words: instruction, functional literacy, life skills

\section{PENDAHULUAN}

Pemberantasan Buta Aksara (PBA) merupakan salah satu program pendidikan pada jalur nonformal yang saat ini sedang dilaksanakan menjadi bagian integral dari upaya pemerintah untuk mengentaskan masyarakat dari kebodohan, kemiskinan, keterbelakangan dan ketidakberdayaan. Program ini bertujuan agar para penyandang buta aksara memperoleh keterampilan dasar untuk baca, tulis, hitung serta mampu berbahasa Indonesia, memperoleh keterampilan-keterampilan fungsional yang bermakna bagi kehidupan sehari-hari, sehingga mereka mampu meningkatkan kualitas kehidupannya. Agar gerakan PBA dapat berjalan baik, pemerintah telah melakukan berbagai upaya mengoptimalkan segala potensi yang ada, salah satunya dengan mengembangkan metode belajar keaksaraan fungsional.

Metode pendekatan belajar keaksaraan fungsional konon dikembangkan atas dasar pemikiran bahwa karakter atau orientasi belajar orang dewasa lebih bersifat praktis dan fungsional serta sesuai dengan potensi dan kebutuhan belajar

Pendidikan
keaksaraan mampu
memberdayakan
masyarakat. Itu bisa
ditunjukkan dari naiknya
penghasilan,
meningkatnya
partisipasi masyarakat
terhadap program
pembangunan, serta
meningkatnya derajat
kesehatan dan gizi.
mereka. Oleh karena itu, penyelenggaraan program keaksaraan fungsional tidak semata-mata memberikan kemampuan baca, tulis, hitung serta kemampuan berbahasa Indonesia dan berpengetahuan dasar akan tetapi lebih jauh memberikan keterampilan-keterampilan fungsional yang bermakna bagi kehidupan warga belajar sehari-hari sehingga mereka mampu meningkatkan kehidupannya.

\footnotetext{
* Penilik Ahli Muda Dinas Pendidikan Kabupaten Kediri Pro. Jawa Timur
}

Pengalaman di lapangan menunjukkan bahwa implementasi program atau gerakan PBA masih mengalami cukup banyak kendala, antara lain rendahnya minat dan motivasi belajar warga belajar, kesulitan tutor untuk memulai pembelajaran, dan belum semua desa dapat teridentifikasi jumlah penduduk yang menyandang buta aksara. Penyebabnya antara lain adalah warga belajar masih malu dan belum tahu manfaat nyata mengikuti pembelajar-an, mereka pada umumnya sibuk bekerja mencari nafkah sehingga tidak memiliki waktu untuk belajar. Terbatasnya jumlah modul dan bahan ajar serta kesempatan mengikuti pelatihan menyebabkan para tutor mengalami kesulitan memulai dan mengelola proses pembelajaran. Keberadaan penduduk penyandang buta aksara terkadang menjadi beban bagi pejabat di daerah seperti Kepala Desa dan Camat, kemungkinan karena malu kalau wilayahnya diketahui banyak penyandang buta aksara. Masih ada pejabat yang enggan memberikan ijin dan akses pendataan sehingga data penduduk buta aksara dinyatakan nihil.

Kendala yang muncul dalam pelaksanaan PBA tersebut perlu segera diatasi. Jika tidak, dikhawatirkan program itu tidak berjalan sebagaimana yang diharapkan dan pada gilirannya target penduduk Indonesia bebas tiga buta (buta aksara latin dan angka, buta pendidikan dasar, dan buta bahasa Indonesia) tidak bisa tercapai. Bisa terjadi suatu daerah sudah dinyatakan bebas tiga buta, tetapi pada suatu saat ditemukan lagi penduduk buta aksara dalam jumlah yang cukup besar, karena pada saat pelaksanaan program mereka tidak teridentifikasi. 
Pembelajaran Keaksaraan Fungsional...

Sebagai contoh, di Kabupaten Kediri jumlah penduduk buta aksara tahun 2002 sebesar 6.537. Pada tahun 2003 telah ditetapkan sasaran dan anggaran untuk 3.320 warga belajar, tahun 2004 untuk 2.320 warga belajar dan tahun 2005 sebanyak 897 warga belajar. Akan tetapi ketika pada awal tahun 2006 dilakukan pendataan, ternyata masih ditemukan 4.383 penduduk buta aksara.

Penelitian UNESCO, seperti tertuang dalam rencana aksi nasional pendidikan keaksaraan, menunjukkan bahwa pendidikan keaksaraan mampu memberdayakan masyarakat. Hal itu terlihat dari naiknya penghasilan, meningkatnya partisipasi masyarakat terhadap program pembangunan, serta meningkatnya derajat kesehatan dan gizi. Dikatakan lebih lanjut bahwa pendidikan keaksaraan juga dapat meningkatkan kesadaran masyarakat untuk menyekolahkan anaknya.

Hasil penelitian UNESCO bahwa pendidikan keaksaraan banyak mendatangkan manfaat dan temuan di lapangan bahwa hingga saat ini program PBA masih mengalami cukup banyak kendala, menjadi motivasi tersendiri bagi penulis untuk melakukan penelitian langsung tentang pembelajaran keaksaraan fungsional dan kecakapan hidup warga belajar. Penelitian ini diharapkan dapat ditemukan model pembelajaran yang inovatif dan aspiratif serta cara-cara baru dalam melakukan identifikasi penduduk buta aksara dan meyakinkan akan pentingnya program keaksaraan fungsional bagi masyarakat.

Masalah Penelitian
Pada dasarnya penelitian ini mempunyai rentangan masalah yang cukup luas. Keluasan tampak pada masalah yang berkaitan dengan proses dan hasil belajar keaksaraan fungsional. Rumusan masalah dalam penelitian ini adalah

1. Apakah pembelajaran keaksaraan fungsional meningkatkan kecakapan hidup warga belajar?

2. Apakah hasil pembelajaran keaksaraan fungsional mengubah sikap Camat pada pelaksanaan Program PBA?

\section{Tujuan Penelitian}

Tujuan penelitian ini adalah untuk mengetahui:

1. Pengaruh pembelajaran keaksaraan fungsional terhadap kecakapan hidup warga belajar, dan

2. Pengaruh hasil pembelajaran keaksaraan fungsional terhadap perubahan sikap Camat pada pelaksanaan Program PBA.

\section{Manfaat Penelitian}

Penelitian ini diharapkan dapat bermanfaat bagi peneliti dan Dinas Pendidikan.

1. Bagi peneliti

Hasil penelitian ini diharapkan berguna untuk mengembangkan proses penalaran ilmiah, meningkatkan pengetahuan, keterampilan serta pengalaman dalam penelitian.

2. Bagi Dinas Pendidikan

Hasil penelitian ini diharapkan dapat membantu usaha-usaha peningkatan layanan pendidikan nonformal bagi masyarakat, yang pada akhirnya dapat meningkatkan mutu pendidikan.

\section{KAJIAN PUSTAKA}

\section{Pembelajaran Keaksaraan Fungsional \\ Pengertian}

Pembelajaran pada hakekatnya. merupakan upaya membelajarkan siswa. Upaya itu dilakukan oleh guru dalam berbagai kegiatan sehingga membuat siswa belajar. Tidak jauh dengan pengertian itu, Dimyati (2006) menyatakan bahwa pembelajaran adalah kegiatan guru secara terprogram dalam desain instruksional untuk membuat siswa belajar secara aktif yang menekankan pada penyediaan sumber belajar.

Keaksaraan fungsional merupakan suatu pendekatan atau cara untuk mengembangkan kemampuan seseorang dalam menguasai dan menggunakan keterampilan menulis, membaca, berhitung, mengamati dan menganalisis yang berorientasi pada kehidupan sehari-hari serta memanfaatkan potensi yang ada di lingkungan sekitarnya (Direktorat Dikmas,1998). Tentang pengertian keaksaraan fungsional, Umberto Sihombing (1999) menyatakan,keaksaraan fungsional adalah pengembangan dari program pemberantasan buta huruf yang bertujuan meningkatkan keaksaraan dasar warga masyarakat buta aksara (warga belajar) sesuai dengan minat dan kebutuhan hidupnya. Pengertian lain dari keaksaraan fungsional adalah program pengembangan kemampuan seseorang dalam menguasai dan menggunakan keterampilan membaca, menulis dan berhitung, serta kemampuan mengamati dan menganalisis yang berorientasi pada kehidupan seharihari dengan memanfaatkan potensi yang ada di lingkungan sekitarnya (Dinas P dan K Jatim, 2006). 
Bertolak dari beberapa pengertian di atas maka pembelajaran keaksaraan fungsional dapat diartikan sebagai proses belajar mengajar untuk mengembangkan kemampuan penyandang buta aksara fungsional dalam menguasai dan menggunakan keterampilan menulis, membaca, berhitung, mengamati dan menganalisis yang berorientasi pada kehidupan seharihari serta memanfaatkan potensi yang ada di lingkungan sekitarnya sebagai sumber belajar.

\section{Tujuan Program Keaksaraan Fungsional}

Tujuan program keaksaraan fungsional adalah membelajarkan peserta didik agar mampu membaca, menulis, berhitung dan berbahasa Indonesia dengan baik dan benar sebagai dasar untuk meningkatkan usaha dan taraf kehidupannya (Direktorat Pendidikan Masyarakat, 2004).

\section{Strategi Program Keaksaraan Fungsional}

Strategi yang dikembangkan dalam program keaksaraan fungsional (Direktorat Pendidikan Masyarakat, 2004) adalah sebagai berikut.

1. Pemberantasan buta huruf dilaksanakan ditingkat grass root yang merupakan basis/ kantung-kantung masyarakat buta huruf, yaitu tingkat RT/RW, pemukiman tertentu, tempat kerja/ perusahaan.

2. Mengoptimalkan pemanfaatan infrastruktur pendidikan yang ada di masyarakat.

3. Mengoptimalkan seluruh potensi sumber daya manusia.

4. Mengoptimalkan peran sekolah, perguruan tinggi, lembaga kursus, lembaga pelatihan swasta, SKB, BPKB, PKBM, balai pendidikan dan latihan, pondok pesantren, majelis taklim dan sebagainya.

5. Menggerakkan peran organisasi sosial kemasyarakatan.

6. Program Pemberantasan Buta Aksara dilaksanakan secara terintegrasi dengan berbagai program penyuluhan, pembimbingan, pendampingan pada masyarakat yang dilakukan berbagai sektor.

7. Program pembelajaran dirancang kontekstual dengan pekerjaan, minat, mata pencaharian, potensi sumber daya alam pertanian, peternakan, perikanan, kelautan, kehutanan, usaha produk kerajinan, pertukangan dan jasa.

8. Kegiatan pembelajaran bisa dilakukan di berbagai tempat dimana saja.

9. Melatih dan menyediakan tenaga pengajar/tutor, bahan belajar yang terkait dengan keterampilan untuk dijadikan mata pencaharian yang dapat memberikan penghasilan.
Aspek-Aspek Dasar Keaksaraan Fungsional

1. Keterampilan dasar

Keterampilan ini berkaitan dengan kemampuan membaca, menulis, dan berhitung (calistung) warga belajar untuk merangkai huruf, merangkai kata, merangkai kalimat, membaca dengan lancar tanpa bantuan orang lain, keterampilan menulis, menulis informasi berdasarkan buah pikirannya sendiri tanpa bantuan orang lain, keterampilan berhitung dengan menggunakan simbol $(+,-, x,:)$, menjumlah (menambahkan), mengurangi, mengali, membagi dan menulis.

\section{Keterampilan fungsional}

Adalah kemampuan warga belajar dalam menggunakan keterampilan membaca, menulis, berhitung, dalam kegiatan sehari-hari, seperti menulis kuitansi, mengisi formulir, membaca petunjuk, menulis surat dII.

\section{Aspek Komponen Program}

Aspek komponen program pada pembelajaran keaksaraan fungsional meliputi warga belajar, tutor, nara sumber teknis, ketenagaan, pembiayaan, sarana dan prasarana (Dinas P dan K Propinsi Jawa Timur, 2006).

\section{Standar kompetensi}

Standar kompetensi disusun sesuai dengan tiga tahap keaksaraan fungsional (Dinas $\mathrm{P}$ dan $\mathrm{K}$ Prop.Jatim, 2006) yaitu:

1. Standar kompetensi pada tahap pemberantasan berdasarkan pengembang-an keterampilan dasar yang sesuai dengan kebutuhan sehari-hari warga belajar.

2. Standar kompetensi pada tahap pembinaan yang dapat membantu warga belajar memanfaatkan calistung dalam kehidupan sehari-hari.

3. Standar pada tahap pelestarian yang dapat membantu warga belajar meningkatkan taraf hidup.

\section{Kecakapan Hidup Warga Belajar}

Pengertian

Ada banyak pengertian tentang kecakapan hidup (life skills) yang dikemukakan oleh para ahli. Menurut Broling (1989), sebagaimana dikutip Ditjen PLSP (2004), life skills adalah interaksi berbagai pengetahuan dan kecakapan yang sangat penting dimiliki oleh seseorang sehingga mereka dapat hidup mandiri. Sedangkan WHO (1997) memberikan pengertian bahwa kecakapan hidup adalah bebagai keterampilan/ kemampuan untuk dapat beradaptasi dan berperilaku positif, yang memungkinkan seseorang mampu 
menghadapi berbagai tuntutan dan tantangan dalam hidupnya sehari-hari secara efektif (Ditjen PLSP, 2004).

Masih tentang pengertian kecakapan hidup, pendapat lain menyatakan bahwa kecakapan hidup adalah kecakapan yang dimiliki oleh seseorang untuk berani menghadapi problema hidup dan kehidupan dengan wajar tanpa merasa tertekan, kemudian secara proaktif dan kreatif mencari serta menemukan solusi, sehingga akhirnya mampu mengatasinya. Sedangkan pengertian warga belajar dalam penelitian ini adalah peserta didik yakni warga masyarakat yang menjadi sasaran program keaksaraan fungsional

Dari beberapa pengertian di atas, dapat dirumuskan bahwa pada hakekatnya kecakapan hidup warga belajar adalah kemampuan yang dimiliki peserta didik untuk hidup mandiri di masyarakat.

\section{Jenis-Jenis Kecakapan Hidup}

Life skills dikelompokkan menjadi tiga kecakapan yaitu, kecakapan hidup sehari-hari (daily living skill), kecakapan hidup pribadi/sosial (personal/social skill) dan kecakapan hidup bekerja (occupational skill) (Ditjen PPLSP, 2004). Lebih lanjut dijelaskan bahwa kecakapan hidup sehari-hari antara lain meliputi pengelolaan kebutuhan pribadi, pengelolaan keuangan pribadi, pengelolaan rumah pribadi, kesadaran kesehatan, kesadaran keamanan, pengelolaan makanan-gizi, pengelolaan pakaian, kesadaran pribadi sebagai warga negara, pengelolaan waktu luang, rekreasi, dan kesadaran lingkungan.

Kecakapan hidup sosial/pribadi antara lain meliputi kesadaran diri minat, bakat, sikap percaya diri, komunikasi dengan orang lain, tenggang rasa dan kepedulian pada sesama, hubungan antar personal, pemahaman dan pemecahan masalah, menemukan dan mengembangkan kebiasaan positif, kemandirian dan kepemimpinan. Sedangkan yang termasuk dalam kecakapan hidup bekerja, meliputi; kecakapan memilih pekerjaan, perencanaan kerja, persiapan keterampilan kerja, latihan keterampil-an, penguasaan kompetensi, menjalankan suatu profesi, kesadaran untuk menguasai berbagai keterampilan, kemampuan menguasai dan menerapkan teknologi, merancang dan melaksa-nakan proses pekerjaan, dan menghasilkan produk barang dan jasa.

Masih tentang kecakapan hidup, WHO (1977) mengelompokkannya ke dalam lima kelompok yaitu kecakapan mengenal diri sendiri (self awareness) atau kecakapan pribadi (personal skill), kecakapan sosial (social skill), kecakapan berpikir (thinking skill), kecakapan akademik (academic skill) dan kecakapan kejuruan (vocational skill)
Penyelenggaraan pendidikan kecakapan hidup pada satuan pendidikan dan program pendidikan nonformal, terutama dalam rangka pengentasan kemiskinan dan penanggulangan pengangguran, lebih ditekankan pada upaya pembelajaran yang dapat memberikan penghasilan atau learning and earning. (Ditjen PLSP, 2004).

\section{Sikap Camat pada Program Pcmberantasan Buta Aksara}

Pengertian

Sikap oleh Fishbein (1975) sebagaimana dikutip Ali dan Asrori (2005) didefinisikan sebagai predisposisi emosional yang dipelajari untuk merespon secara konsisten terhadap suatu obyek. Sikap merupakan variabel laten yang mendasari, mengarahkan, dan mempengaruhi perilaku. Sikap tidak identik dengan respons dalam bentuk perilaku, tidak dapat diamati secara langsung tetapi dapat disimpulkan dari konsistensi perilaku yang diamati. Secara operasional, sikap dapat diekspresikan dalam bentuk kata-kata atau tindakan yang merupakan respons reaksi dari sikapnya terhadap objek, baik berupa orang, peristiwa, atau situasi (Horocks, 1976).

Sementara itu, Chaplin (1981) dalam Dictionary Psychology menyamakan sikap dengan pendirian. Sikap sebagai predisposisi atau kecenderungan yang relatif stabil dan berlangsung terus-menerus untuk bertingkah laku atau bereaksi dengan cara tertentu terhadap orang lain, objek, lembaga atau persoalan tertentu. Dilihat dari sudut pandang yang agak berbeda, sikap merupakan kecenderungan untuk bereaksi terhadap orang, lembaga atau peristiwa, baik secara positif maupun negatif. Sikap itu secara khas mencakup suatu kecenderungan untuk melakukan klasifikasi dan kategorisasi (Ali dan Asrori, 2005). Dari beberapa definisi tersebut di atas, secara sederhana sikap dapat diartikan sebagai reaksi terhadap rangsangan yang datang.

Camat adalah Kepala Kecamatan (Pemkab Kediri, 2003). Sedangkan Kecamatan menurut Peraturan Pemerintah Republik Indonesia Nomor 8 Tahun 2003 tentang Pedoman Organisasi Perangkat Daerah merupakan perangkat daerah Kabupaten/Kota yang mempunyai wilayah kerja tertentu, dipimpin oleh Camat yang berada di bawah dan bertanggung jawab kepada Bupati/Walikota melalui Sekretaris Daerah Kabupaten/Kota. PBA terdiri atas tiga kata, yakni pemberantasan, buta dan aksara. Untuk memahami pengertiannya dapat dikelompokkan menjadi dua yakni pemberantasan dan buta aksara. Pemberantasan adalah proses, cara, perbuatan memberantas (Umi 
Basiroh dkk, 1988). Buta aksara adalah seseorang yang tidak dapat membaca, menulis dalam huruf latin dan berhitung dengan angka Arab (Direktorat Pendidikan Masyarakat, 2003). Dengan demikian PBA dapat diartikan sebagai upaya atau program pemerintah agar para penyandang buta aksara dapat membaca, menulis dan berhitung.

\section{Pembentukan dan Perubahan Sikap}

Menurut Abu Ahmadi (2002) sikap timbul karena ada stimulus. Terbentuknya suatu sikap itu banyak dipengaruhi perangsang oleh lingkungan sosial dan kebudayaan. Sikap seseorang tidak selamanya tetap. la dapat berkembang manakala mendapat pengaruh, baik dari dalam maupun dari luar yang bersifat positif dan mengesankan antara perbuatan dan sikap ada hubungan timbal balik. Tetapi sikap tidak selalu menjelma dalam bentuk perbuatan atau tingkah laku. Orang kadang-kadang menampakkan diri dalam keadaan "diam" saja.
Seorang Camat selaku perangkat daerah dalam pelaksanaan program PBA bisa bersikap pasif dalam arti tidak berbuat apa-apa atau "diam". Hal ini dilakukan karena adanya anggapan bahwa bila terdapat jumlah penyandang buta aksara banyak di suatu wilayah maka Camatnya dinilai kurang berhasil dalam pembangunan. Pada gilirannya anggapan tersebut akan berpengaruh terhadap penilaian prestasi kerja pejabat wilayah tersebut. Sikap pasif tersebut biasanya diwujudkan dengan kecenderungan tidak memberikan akses dan fasilitas yang sewajarnya terhadap program yang sedang berjalan. Akan tetapi kecenderungan sikap negatif tersebut sangat mungkin bisa berubah manakala ada pengaruh dari lingkungan sekitar. Misalnya, dengan memberikan informasi yang benar kepada Camat itu tentang manfaat program PBA dan hasil yang telah dicapai oleh warga belajar yang telah mengikuti program tersebut.

\section{METODOLOGI PENELITIAN}

\section{Prosedur Penelitian}

Penelitian ini merupakan penelitian deskriptif untuk memberikan gambaran tentang peningkatan pembelajaran keaksaraan fungsional dan kecakapan hidup warga belajar dan perubahan sikap camat pada program PBA.

Ada enam langkah yang ditempuh dalam penelitian ini. Secara rinci masing-masing langkah dapat dijelaskan sebagai berikut.

Tahap pertama, dalam langkah persiapan dilakukan kegiatan-kegiatan meliputi: mengkoordinasikan jadwal penelitian dengan pengelola dan tutor kelompok belajar, mempersiapkan paket materi, bahan, media, dan peralatan pretest. Tahap kedua, melakukan pretest sebelum kegiatan pembelajaran dilaksanakan. Pretest dilakukan pada setiap materi yang akan dibelajarkan. Tahap ketiga, proses pembelajaran berlangsung (perlakuan), dilakukan observasi terhadap aktifitas warga belajar. Tahap keempat, setelah proses pembe-lajaran selesai dilakukan post test untuk mengetahui hasil akhir pembelajaran. Tahap kelima, menyampaikan kepada Camat tentang hasil penelitian dan meminta respons atas kegiatan dan hasil pembelajaran. Tahap keenam, menindaklanjuti respons Camat atas hasil penelitian untuk pelaksanaan dan pengembangan program PBA pada kesempatan yang akan datang.

Prosedur penelitian ini secara garis besar dapat digambarkan sebagai berikut.

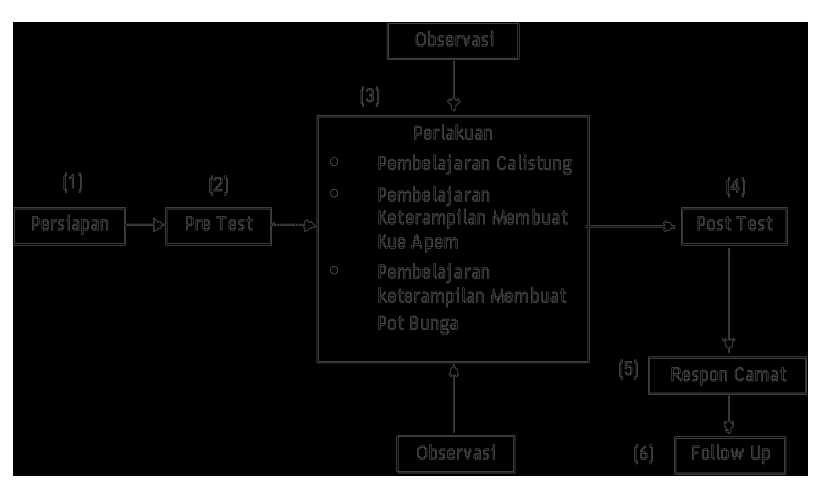

Gambar: Prosedur penelitian

\section{Tempat dan Waktu Penelitian}

Penelitian ini dilakukan di Desa Gayam, Kecamatan Gurah, Kabupaten Kediri dengan menggunakan dua kelompok belajar dan di Desa Turus, Kecamatan Gurah dengan menggunakan satu kelompok belajar. Setiap kelompok belajar beranggotakan sepuluh warga belajar.

Penelitian dilaksanakan mulai bulan Agustus 2005 sampai dengan Januari 2006.

\section{Populasi}

Populasi penelitian ini adalah warga belajar pada tiga kelompok belajar keaksaraan fungsional di Kecamatan Gurah, Kabupaten Kediri. Anggota populasi adalah semua warga belajar berjumlah tiga puluh orang. Karena dalam penelitian ini jumlah obyek atau anggota populasinya kecil maka seluruh populasi digunakan 
Pembelajaran Keaksaraan Fungsional...

sebagai sumber data. Penggunaan seluruh populasi sebagai sumber data ini, disebut penelitian populasi atau penelitian dengan sampel total (Hadari Nawawi, 1987) sebagaimana dikutip Nurulyati (1999) dan sejalan dengan pendapat lain bahwa jika besarnya populasi terbatas, peluang rambang dapat diberikan kepada anggota-anggota populasi secara individual (Sumadi Suryabrata, 2000).

\section{Metode Pengumpulan Data.}

1. Melakukan wawancara

Dalam penelitian ini juga digunakan teknik wawancara tertutup untuk mengetahui sikap Camat selaku perangkat daerah terhadap program Pemberantasan Buta Aksara yang dilaksanakan sebelum dan sesudah kegiatan pembelajaran keaksaraan fungsional. Walaupun cara demikian tidak terlalu sesuai dengan penelitian kualitatif yang biasanya berpandangan terbuka sebagaimana diungkapkan Lexy J. Moleong (2000), tetapi cara ini lebih memungkinkan untuk memperoleh data dan fakta apa adanya dibandingkan bila menggunakan wawancara terbuka.

\section{Menyelenggarakan tes}

Instrumen berbentuk tes digunakan untuk mengetahui seberapa jauh penguasaan kecakapan hidup warga belajar. Tes yang dikembangkan meliputi uji awal atau pre test yang dilaksanakan secara lisan sebelum kegiatan pembelajaran keaksaraan fungsional. Teknik ini digunakan karena sumber data merupakan penyandang buta aksara. Selain itu dilakukan uji akhir atau post test dalam bentuk tes tulis setelah proses pembelajaran keaksaraan fungsional selesai.

3. Melakukan observasi

Observasi dilakukan untuk mengetahui seberapa jauh warga belajar secara praktis menguasai materi pembelajaran baik berupa kemampuan membaca, menulis, dan berhitung maupun penguasaan keterampilan memasak, menjahit dan membuat pot bunga.

\section{Analisis Data.}

Analisis data menggunakan statistik deskriptif dengan menggunakan mean dan persentase. Selain itu dilakukan analisis kualitatif yang berdasarkan pemikiran logis.

\section{HASIL PENELITIAN}

\section{Kemampuan membaca, menulis, dan berhitung}

Setiap warga belajar diberikan tes sebelum proses pembelajaran dilaksanakan (uji awal) dan tes yang sama diberikan lagi pada saat kegiatan proses pembelajaran telah selesai dilaksanakan (uji akhir). Hasil tes untuk kemampuan membaca, menulis, dan berhitung (Calistung) disajikan dalam bentuk proporsi pada setiap kompetensi seperti tampak di tabel 1. Dari tabel tersebut tampak bahwa terjadi kenaikan proporsi kemampuan (jawaban benar) rata-rata dari 0,30 (uji awal) menjadi 0,79 (uji akhir).

Memperhatikan skor rata-rata uji akhir memberi petunjuk bahwa sekitar 79 persen materi pembelajaran keaksaraan fungsional dikuasai warga belajar setelah mengikuti proses pembelajaran. Bila dilihat pada masing-masing kompetensi, terlihat bahwa skor tertinggi uji akhir pada kompetensi berhitung.
Tabel 1. Hasil uji awal dan uji akhir pembelajaran keaksaraan fungsional

\begin{tabular}{|c|l|c|c|}
\hline No & \multicolumn{1}{|c|}{ Kompetensi } & \multicolumn{2}{|c|}{ Proporsi Jawaban Benar } \\
\cline { 3 - 4 } & & Uji Awal & Uji Akhir \\
\hline 1 & \multicolumn{1}{|c|}{2} & 3 & 4 \\
\hline 1 & Mengisi formulir & 0.33 & 0,77 \\
2 & Menyusun langkah-langkah proses & 0.29 & 0.78 \\
3 & Berhitung & 0.34 & 0.85 \\
4 & Penerapan belajar dalam kehidupan sehari- & 0,29 & 0.77 \\
5 & hari Memahami bacaan & 0.28 & 0.79 \\
\hline & Rata- rata & 0,30 & 0,79 \\
\hline
\end{tabular}

Sementara itu, apabila dilihat dari peningkatan proporsi jawaban benar, kompetensi nomor 3 dan 5 memperoleh hasil yang paling tinggi, yaitu sebesar 0,51 . Untuk kompetensi tiga meningkat dari 0,34 pada uji awal menjadi 0,85 pada uji akhir, sedangkan kompetensi lima meningkat dari 0,28 pada uji awal menjadi 0, 79 pada uji akhir.

\section{Penguasaan Keterampilan Membuat Kue Apem}

Observasi dilakukan oleh tutor dan pengamat luar kemudian hasilnya dirata-rata. Data tentang penguasaan warga belajar atas keterampilan membuat kue apem tertera pada tabel 2 . 
Tabel 2. Hasil observasi tentang penguasaan warga belajar atas keterampilan praktis membuat kue apem

\begin{tabular}{|c|l|c|}
\hline No & Aspek Keterampilan Praktis & Skor Rata-rata \\
\hline 1 & \multicolumn{1}{|c|}{2} & 3 \\
\hline 1 & Pemilihan alat & 3.43 \\
2 & Pemilihan bahan & 3.3 \\
3 & Penyortiran bahan & 3.21 \\
4 & Penyampuran bahan & 3.36 \\
5 & Penggunaan alat & 3.43 \\
6 & Pemanggangan apem & 3.38 \\
7 & Pembungkusan apem & 3.32 \\
8 & Analisis biava pembuatan apem & 3.31 \\
\hline & Rata-rata & 3.34 \\
\hline
\end{tabular}

Keterangan : Rentang Nilai $1.00-4.00$

Memperhatikan angka-angka pada tabel tersebut, tampak bahwa warga belajar memperoleh skor rata-rata keterampilan praktis sebesar 3,34 dari rentang skor 1,00-4,00. Data tersebut menunjukkan bahwa penguasaan warga belajar terhadap bahan pelajaran yang terkait psikomotor baik.

\section{Penguasaan Keterampilan Membuat Pot Bunga}

Apabila diamati lebih rinci, di antara kelima aspek keterampilan yang diungkap sebagaimana tertera pada tabel 3 berikut ini, aspek penggunaan alat memperoleh skor tertinggi, sementara itu aspek pencetakan pot memperoleh skor paling rendah. Ditinjau dari karakteristik bahan pelajaran, aspek pencetakan pot cenderung memiliki kesulitan lebih tinggi dari aspek yang lain. Tingkat kesulitan itu antara lain berupa penentuan komposisi campuran bahan.

Tabel 3. Hasil observasi tentang penguasaan warga belajar atas keterampilan praktis membuat pot bunga

\begin{tabular}{|c|l|c|}
\hline No & \multicolumn{1}{|c|}{ Apek Keterampilan Praktis } & $\begin{array}{c}\text { Skor Rata- } \\
\text { rata }\end{array}$ \\
\hline 1 & \multicolumn{1}{|c|}{2} & 3 \\
\hline 1 & Pemilihan alat & 3,43 \\
2 & Pemilihan bahan & 3,33 \\
3 & Penggunaan alat & 3,41 \\
4 & Pencampuran bahan & 3,55 \\
5 & Pencetakan pot & 3,3 \\
6 & Pelepasan cetakan & 3,35 \\
7 & Finishing (penghalusan \& pengecatan) & 3,38 \\
8 & Analisis biaya pembuatan pot & 3,34 \\
\hline & Rata-rata & 3,38 \\
\hline
\end{tabular}

\section{Sikap Camat Terhadap Program Pemberantasan Buta Aksara}

Data tentang sikap Camat terhadap program PBA diperoleh melalui wawancara tertutup dilakukan sebelum dan sesudah penelitian. Dari tabel 4 berikut diketahui bahwa pada wawancara awal aspek rencana pendataan memperoleh skor terendah yaitu 1 dari rentang skor 1,00-5,00, tetapi pada wawancara akhir memperoleh skor tertinggi yaitu 5 , bersama dengan aspek rencana penyelenggaraan pembelajaran keaksaraan fungsional.

Tabel 4. Hasil wawancara tertutup dengan camat tentang program pemberantasan buta aksara

\begin{tabular}{|c|c|c|c|}
\hline \multirow{2}{*}{ No } & \multirow[b]{2}{*}{ Aspek yang ditanyakan } & \multicolumn{2}{|c|}{ Skor } \\
\hline & & $\begin{array}{c}\text { Wawancara } \\
\text { Awal }\end{array}$ & $\begin{array}{l}\text { Wawancara } \\
\text { Akhir }\end{array}$ \\
\hline 1 & 2 & 3 & 4 \\
\hline 1 & $\begin{array}{l}\text { Jumlah penduduk buta aksara di wilayah } \\
\text { Kecamatan Gurah }\end{array}$ & 2 & 4 \\
\hline 2 & $\begin{array}{l}\text { Rencana dilakukan pendataan penduduk buta } \\
\text { aksara di Kecamatan Gurah }\end{array}$ & 1 & 5 \\
\hline 3 & $\begin{array}{l}\text { Anggapan bahwa keberadaan penduduk buta } \\
\text { aksara menjadi beban bagi pejabat }\end{array}$ & 2 & 3 \\
\hline 4 & $\begin{array}{l}\text { Manfaat kegiatan pembelajaran keaksaraan } \\
\text { fungsional bagi warganya }\end{array}$ & 3 & 4 \\
\hline 5 & $\begin{array}{l}\text { Rencana penyelenggaraan kegiatan pembelajaran } \\
\text { keaksaraan fungsional di Kecamatan Gurah }\end{array}$ & 2 & 5 \\
\hline & Rata- rata & 2,2 & 4,2 \\
\hline
\end{tabular}

Keterangan : Rentang Skor 1,00-5,00

\section{Pembahasan Hasil Penelitian.}

Kemampuan Membaca Menulis dan Berhitung

Setelah dilakukan pembelajaran membaca, menulis dan berhitung melalui metode keaksaraan fungsional, sebesar 79 persen materi dikuasai oleh warga belajar yang sebelumnya warga belajar telah menguasai 30 persen. Dengan demikian terjadi peningkatan penguasaan materi pembelajaran sebanyak 49 persen. Data lain menunjukkan bahwa kompetensi berhitung dan memahami bacaan mengalami peningkatan paling tinggi yaitu sebesar 51 persen. Sedangkan peningkatan paling rendah terjadi pada kompetensi mengisi formulir, yakni sebesar 44 persen.

Penguasaan Keterampilan Praktis Membuat Kue Apem

Keterampilan praktis membuat kue apem secara umum dapat dikuasai oleh warga belajar setelah selesai mengikuti proses pembelajaran. Aspek keterampilan penggunaan alat memperoleh nilai tertinggi yaitu sebesar 3,43 dari rentang skor 1,00-4,00, sama dengan nilai aspek keterampilan pemilihan alat. Penguasaan warga belajar atas keterampilan praktis membuat kue apem berarti menambah kecakapan hidup mereka.

Penguasaan Keterampilan Praktis Membuat Pot Bunga

Peningkatan kecakapan hidup warga belajar setelah mengikuti pembelajaran keaksaraan fungsional juga ditunjukkan dengan penguasaannya atas keterampilan praktis membuat pot bunga, yang secara 
rata-rata mendapat nilai 3,38 dari rentang skor 1,00 4,00. Nilai tertinggi pada aspek keterampilan mencampur bahan yaitu sebesar 3,55 diikuti pemilihan dan penggunaan alat yang masing-masing mendapat nilai 3,43 dan 3,41.

Perubahan Sikap Camat Pada Program Pemberantasan Buta Aksara

Penelitian ini dilaksanakan antara lain dilatarbelakangi oleh masih adanya kendala dalam pelaksanaan program Pemberantasan Buta Aksara di lapangan. Kendala tidak hanya datang dari warga belajar dan masyarakat, tetapi juga dari sikap mental pejabat yang masih berpandangan bahwa keberadaan penduduk buta aksara di wilayahnya tidak perlu diketahui. Pandangan tersebut bisa terjadi antara lain karena belum ada informasi yang didapat tentang manfaat program PBA, terbukti bahwa setelah mendapatkan informasi yang benar tentang manfaat pembelajaran keaksaraan fungsional, seorang Camat yang sebelumnya tidak mengijinkan dilakukan pendataan penduduk buta aksara di wilayahnya berbalik mendukung kegiatan tersebut.

\section{Tindak Lanjut.}

\section{Pendataan}

Agar memperoleh data secara cepat dan benar, kegiatan pendataan melibatkan 90 Guru Taman KanakKanak yang tinggal di Kecamatan Gurah. Kegiatan dilaksanakan mulai tanggal 15-25 Maret 2006.

Hasil pendataan menunjukkan bahwa jumlah penduduk buta aksara sebanyak 950 dengan rincian usia 15-44 tahun sebanyak 531 yang terdiri dari 273 laki-laki dan 258 perempuan. Sedangkan usia 44-50 tahun sebanyak 419 terdiri dari 102 laki-laki dan 318 perempuan.

Jumlah ini meningkat tajam bila dibandingkan dengan data tahun 2002 yang menyebutkan bahwa jumlah penduduk buta aksara sebanyak 276 .

\section{Pelaporan dan Rencana Aksi}

Hasil pendataan dilaporkan ke Dinas Pendidikan Kabupaten Kediri. Pada tahun 2006 Kecamatan Gurah mendapat alokasi anggaran Pemberantasan Buta Aksara dari APBD untuk 70 kelompok belajar dengan sasaran 700 warga belajar. Kegiatan akan dilaksanakan mulai bulan Juli. PGRI telah ditunjuk sebagai penyelenggara dan calon tutor adalah guru-guru TK yang melakukan pendataan.

\section{KESIMPULAN DAN SARAN}

\section{Kesimpulan}

Berdasarkan deskripsi hasil dan pembahasan yang telah diuraikan pada pembahasan hasil penelitian dapat disimpulkan sebagai berikut:

1. Setelah dilakukan proses pembelajaran sebanyak 79 persen materi pembelajaran berupa kemampuan membaca, menulis, dan berhitung dapat dikuasai warga belajar. Kompetensi berhitung memperoleh skor tertinggi, yaitu sebesar 85 dari rentang skor 1100.

2. Setelah mengikuti pembelajaran Keaksaraan Fungsional warga belajar memperoleh temuan kecakapan hidup berupa Keterampilan praktis membuat kue apem yang dikuasai oleh warga belajar dengan nilai rata-rata 3,34 dari rentang skor 1,00-4,00. Nilai tersebut menunjukkan bahwa penguasaan warga belajar atas keterampilan membuat kue apem baik.

3. Warga belajar memperoleh nilai rata-rata 3,38 atas penguasaan keterampilan praktis membuat pot bunga dari rentang skor 1,00 - 4,00, hal ini menunjukkan bahwa keterampilan praktis tersebut dapat dikuasai dengan baik oleh warga belajar dan pada gilirannya dapat digunakan untuk sebagai bekal mencari tambahan penghasilan.

4. Setelah mengetahui akan manfaat pembelajaran keaksaraan fungsional bagi warga belajar, terjadi perubahan sikap Camat pada program PBA. Bila sebelumnya cenderung memberi respons negatif berubah positif dengan mendukung sepenuhnya pelaksanaan program tersebut.

\section{Saran}

1. Agar pelaksanaan program PBA terus dilaksanakan dengan lebih banyak lagi mengembangkan dan meningkatkan pembelajaran aspek keterampilan praktis.

2. Sosialisasi program PBA kepada masyarakat, termasuk para pejabat, secara kualitas maupun kuantitas perlu terus ditingkatkan. 


\section{DAFTAR PUSTAKA}

Ahmadi, A. (2002). Psikologi sosial. Jakarta: PT. Rineka IImu

Ali, M. H. \& Asrori. (2005). Psikologi remaja perkembangan peserta didik. Jakarta: PT. Bumi Aksara.

Dimyati \& Mudjiono. (2006).Belajar dan pembelajaran. Jakarta: PT Rineka Cipta.

Himpunan peraturan daerah kabupaten Kediri tentang pemerintahan desa. (2003). Kediri: Pemerintah Kabupaten Kediri.

Moleong, L. J. (2000). Metodologi penelitian kualitatif. Bandung: PT. Remaja Rosdakarya.

Nurulyati. (1999). Pengaruh hasil belajar PPKn anak tunagrahita terhadap pelaksanaan tata tertib sekolah di SLB Dharma Wanita Kediri. Skripsi. Kediri: FPIPS IKIP PGRI Kediri.

Pedoman penyelenggaraan program kecakapan hidup (life skills) pendidikan luar sekolah. (2004). Jakarta: Direktorat Pendidikan Masyarakat, Ditjend PLSP, Depdiknas.

Pedoman penyelenggaraan program kelompok belajar keaksaraan fungsional. (2003). Jakarta:
Direktorat Pendidikan Masyarakat, Ditjend PLSPO, Depdiknas.

Peraturan perundang-undangan pedoman organisasi perangkat daerah. (2004). Bandung: Fokus media.

Petunjuk pelaksanaan pemberantasan buta aksara. (2006). Surabaya: Subdin PLS Dinas Pendidikan dan Kebudayaan Propinsi Jawa Timur.

Profil Direktorat Pendidikan Masyarakat 2004: Menuju masyarakat yang cerdas, terampil, dan mandiri. (2004). Jakarta: Direktorat Pendidikan Masyarakat, Ditjend PLSP, Depdiknas.

Sihombing, U. (1999). Pendidikan luar sekolah kini dan masa depan: Konsep, kiat dan pelaksanaan. Jakarta: PD. Mahkota. Suryabrata.

Sumadi. (2000). Metodologi penelitian. Jakarta: PT. Raja Grafindo Persada.

Umi dkk. (1988). Kamus besar bahasa Indonesia. Jakarta: Balai Pustaka.

Undang-undang no. 20 tahun 2003 tentang sistem pendidikan nasional. (2003). Jakarta: Cemerlang. 